\title{
Rare Case of Intestinal Mass: Ganglioneuroma
}

\section{Nadir bir Bağırsak Kitlesi Olgusu: Ganglionöroma}

\author{
(1) Sami Benli1, (1) Tufan Egeli2, (1) Cihan Ağalar2, (1) Anıl Aysal Ağalar3 \\ ${ }^{1}$ Mersin University Faculty of Medicine, Department of General Surgery, Division of Oncological Surgery, Mersin, Turkey \\ 2Dokuz Eylül University Faculty of Medicine, Department of General Surgery, İzmir, Turkey \\ 3Dokuz Eylül University Faculty of Medicine, Department of Pathology, İzmir, Turkey
}

\section{HIIIIII| ABSTRACT}

Ganglioneuroma (GN) is a rare, slow-growing, benign, neurogenic tumor that often originates from sympathetic ganglion cells and rarely from the adrenal medulla, sympathetic nerves, and peripheral nerves. Mediastinum and retroperitoneum are the most common locations, but they may occur in any part of the gastrointestinal system. This patient, who presented to our clinic with abdominal pain, had two hypodense lesions in the liver and pulmonary nodules in the lung, which caused invagination at the terminal ileum-ileocecal valve level. She underwent right colectomy, and the histopathological diagnosis was GN.

Keywords: Ganglioneuroma, intestinal mass, neurogenic tumor

\section{|IIIIIII| ÖZ}

Ganglionöroma (GN), sıklıkla sempatik ganglion hücrelerinden ve nadiren adrenal medulla, sempatik sinirler ve periferik sinirlerden kaynaklanan, nadir görülen, yavaş büyüyen, iyi huylu, nörojenik bir tümördür. Mediasten ve retroperiton en sık görülen yerlerdir, ancak gastrointestinal sistemin herhangi bir yerinde görülebilirler. Kliniğimize karın ağrısı ile başvuran ve ileri tetkikler sonucunda terminal ileum-ileoçekal kapak seviyesinde invajinasyona neden olan, karaciğerde hipodens iki lezyon ve akciğerde pulmoner nodüller bulunan hastaya sağ kolektomi ve histopatolojik tanı GN olarak rapor edildi.

Anahtar Kelimeler: Ganglionöroma, intestinal kitle, nörojenik tümör

\section{Introduction}

Intestinal ganglioneuromatosis (IGNM) is a rare, neoplastic condition characterized by marked proliferation of the ganglion cells, Schwann cells, and nerve fibers in the wall of the bowel. ${ }^{1}$ Ganglioneuroma (GN) is very rare in the gastrointestinal (GI) system. Intestinal GN is divided into three groups, polypoid GN, ganglioneuromatosis, and diffuse ganglioneuromatosis, according to the degree of differentiation. ${ }^{1}$ Polypoid ganglioneuromatosis may be seen together with intestinal polyposis, neurofibromatosis type 1 , and Cowden syndrome. ${ }^{2}$

Its clinical expression is variable. The polypoid form of ganglioneuromatosis may be solitary, in which patients have single colonic polyps composed of spindle and ganglion cells or multiple polyps, most commonly in the terminal ileum and colon, also known as ganglioneuromatous polyposis. The diffuse form is characterized by hyperplasia of the myenteric plexus and transmural proliferation of ganglioneuromatous tissue in the bowel wall. ${ }^{2}$ The clinical condition varies according to the location of the lesion and its spread and effect on intestinal motility. The most common symptoms are abdominal pain, signs of obstruction, and changes in bowel habits. This condition may affect any segment of the GI tract, but the ileum, colon, and appendix are most frequently involved. ${ }^{3}$ 


\section{Case Report}

A 44-year-old female was evaluated in an external center for symptoms of abdominal pain, constipation, and invagination at the level of the terminal ileum and ileocecal valve, and two hypodense lesions in the liver and nodules in the lung were detected on abdominal tomography, for which she was referred to our center.

In the thoracoabdominal computed tomography (CT), 10$\mathrm{mm}$ and 15-mm hypodense lesions in segment 7 of the liver, a 1-cm pulmonary nodule located in the lower lobe of the right lung, and cecal 10x5.5 cm conglomerated bowel loops were observed, which were initially interpreted as malignancy.

Double balloon enteroscopy was performed by the gastroenterologist, and a 5-cm ulcerated lesion protruding toward the lumen at the terminal ileum level was detected. The biopsy result was reported as fibrinoproplated exudate and active granulation tissue.

Diagnostic positron emission tomography CT was performed on the patient, who could not have been diagnosed with the result of the biopsy. Focal increased F-18 FDG uptake was noted in the right lower quadrant, possibly in the ileum $\left(\mathrm{SUV}_{\max }: 5.5\right)$, and lesions in the lungs and liver were reported to be benign.

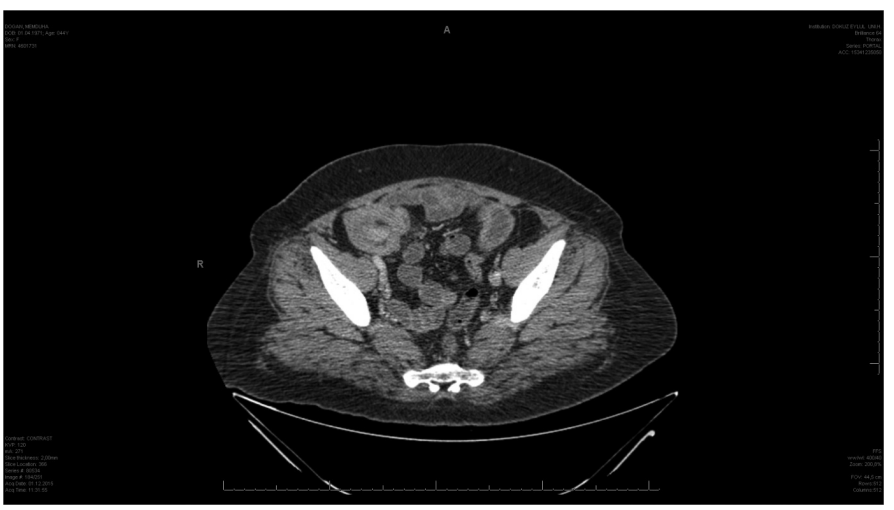

Figure 1. Conglomerated mass in the right lower quadrant

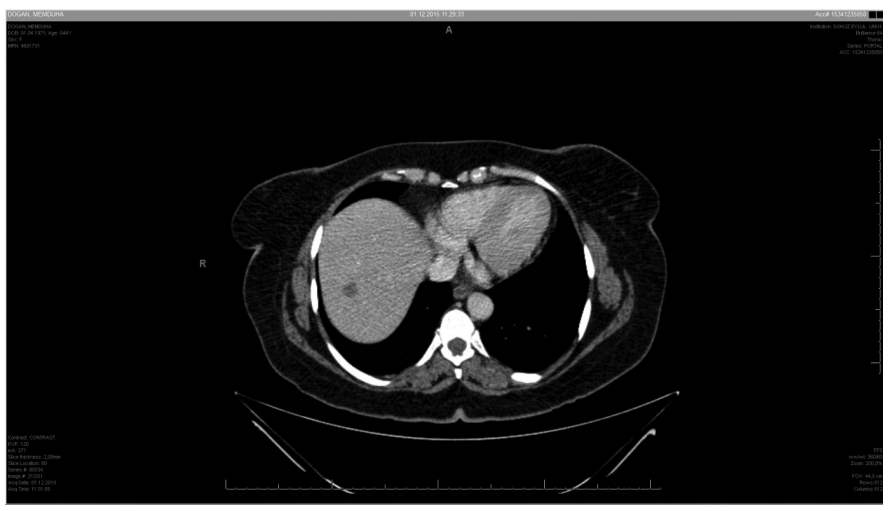

Figure 2. Hypodense lesion in segment 7 of the liver
The patient underwent right colectomy, including the terminal ileum, and its pathology was reported as GN.

On macroscopic examination of the small intestine resection material, in the small intestine segment with a length of $15 \mathrm{~cm}$, an area with an appearance compatible with invagination was observed at one end, which was approximately $1.5 \mathrm{~cm}$ from the surgical margin. When the intestine was opened along the lumen, a $4.1 \times 3 \times 1-\mathrm{cm}$, graywhite, well-circumscribed lesion, which was thought to originate from under the mucosa, was observed on the wall of the 8-cm long invaginated bowel segment.

Microscopic examination revealed a nodular submucosal lesion with a well-circumscribed border (Figure 4). It was observed that this lesion comprised spindle cells and ganglion cells (Figure 5). Cytological atypia and mitotic activity were not observed in the cells forming the lesion. On immunohistochemical examination, staining was observed only with CD56 in ganglion cells. With the present morphological and immunohistochemical findings, the case was evaluated as a GN.

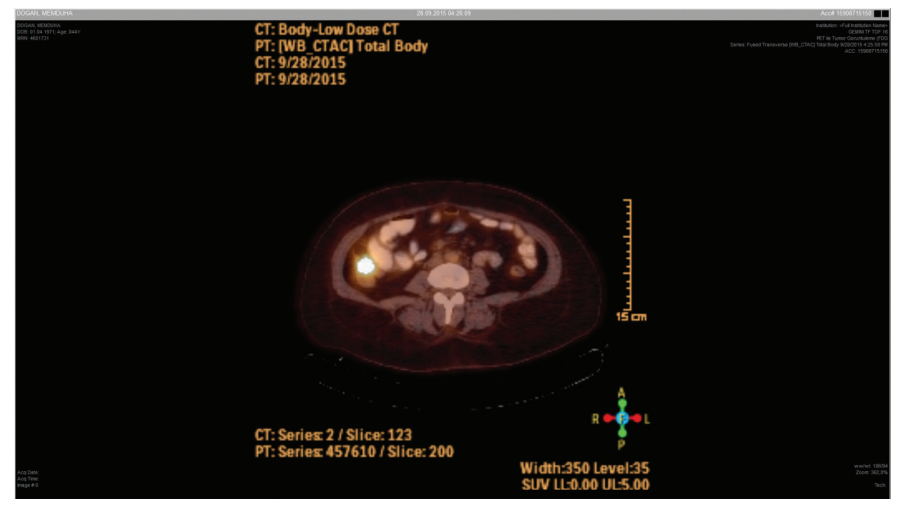

Figure 3. Focal increased F-18 FDG uptake was noted in the right lower quadrant, possibly in the ileum $\left(\mathrm{SUV}_{\max }: 5.5\right)$

FDG: Florodeoxyglucose

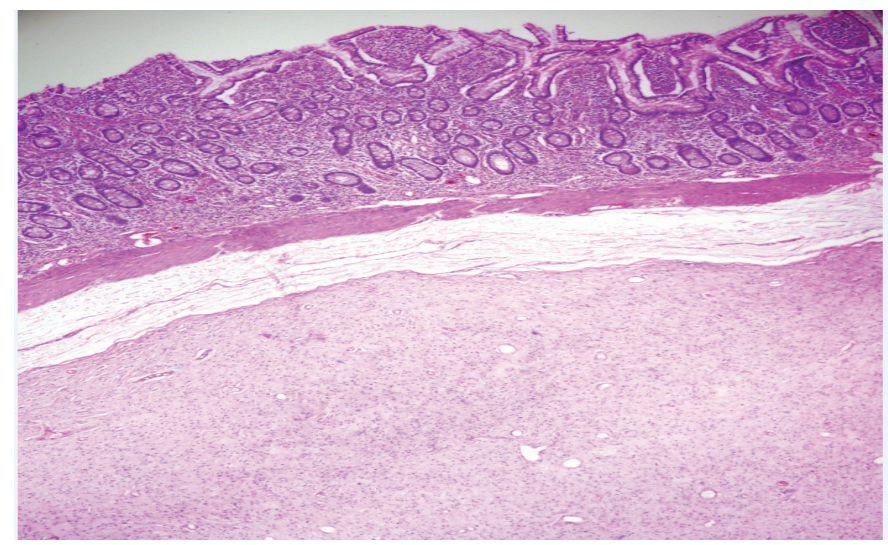

Figure 4. Well demarcated nodular lesion in the small intestine, located in the submucosa, $\mathrm{x} 10, \mathrm{H} \& \mathrm{E}$ 


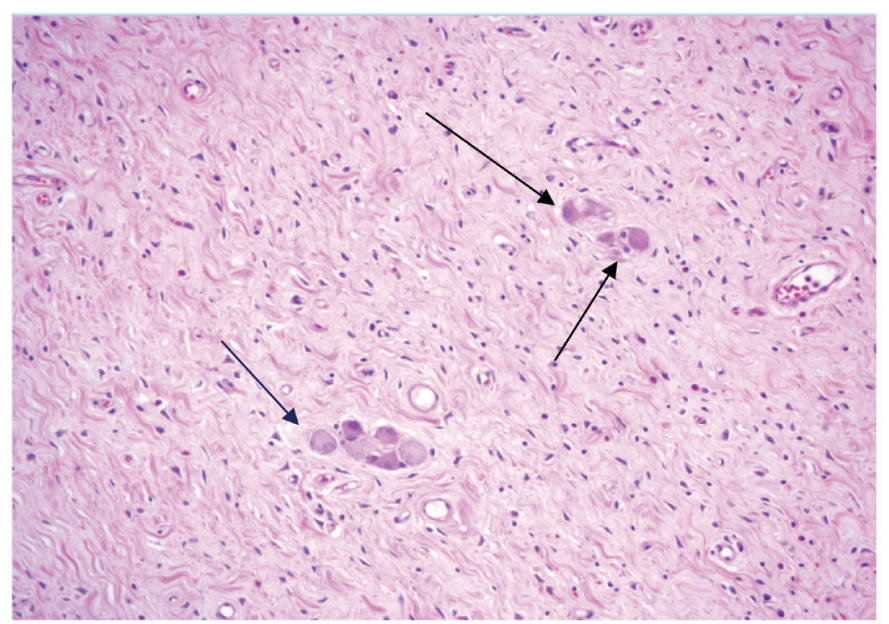

Figure 5. Spindle cell proliferation and lesion consisting of ganglion cells, x20, H\&E

\section{Discussion}

GN is a subgroup of peripheral neurogenic tumors. It is defined as a tumor that originates from the neural crest and develops by migrating to the neuroectodermal cells. ${ }^{4}$ Peripheral neurogenic tumors are divided into three subgroups, namely, neuroblastoma, ganglioneuroblastoma, and GN, according to the degree and type of neuroblastic differentiation, malignancy potential, and Schwann stroma development. ${ }^{5}$ Among these, GN is a rare, slowgrowing tumor with a benign character, often arising from sympathetic ganglion cells or adrenal medulla cells. It is composed histologically of ganglion cells and includes Schwann cells and fibrous tissue.

Although the most common regions are reported as the posterior mediastinum and retroperitoneal area, the adrenal gland is involved in $21 \%{ }^{6}$ More rarely, they may be seen simultaneously in the mediastinum and retroperitoneal region or may be localized in the parapharyngeal area, bone, GI system, and supraclavicular region. ${ }^{3}$ It is generally encountered in the pediatric age group, two third of the cases are under the age of 20 years. ${ }^{7}$ Because of its slow growth, it is usually diagnosed in late adolescence. Its symptoms are usually caused by the compression of the tumor by the surrounding tissue. In these cases, clinical findings, such as persistent cough and shortness of breath, manifest themselves. In addition to neural compression, dorsal spinal scoliosis, increased catecholamine secretion due to the secretory activity, and metabolic problems may also be rarely encountered. ${ }^{5}$

Intestinal GNs are rare, benign neoplastic lesions characterized by certain pathological findings. In some patients, solitary lesions, such as colonic polyps, may occur as multiple polyposes, called ganglioneuromatosis, seen in the colon and the terminal ileum in others. In some patients, wall thickness increases in the form of proliferation in the myenteric plexus and infiltration of the IGNM cells in the intestinal wall. IGNM mostly involves the colon, terminal ileum, and the appendix. ${ }^{8}$

When IGNM affects the terminal ileum, it causes an increase in the thickness of the intestinal wall, submucosal nodular proliferation, and stricture formation. Its symptoms are abdominal pain and diarrhea. In our patient, due to abdominal tomography, an increase in the wall thickness at the ileocecal junction in the right lower quadrant and the interlocking of intestinal segments compatible with invagination at this level were observed.

Increased intestinal wall thickness, luminal narrowing, invagination, presence of mesenteric lymph nodes, and nodular hypodense lesions in the liver and lungs, which may be seen in abdominal tomography, may easily overlook the diagnosis of intestinal GN.

As a differential diagnosis, inflammatory bowel diseases, chronic ischemic changes, radiation effect, CMV infections, intestinal tuberculosis, lymphoma, GI stromal tumors, and amyloidosis may be considered. ${ }^{9}$

The treatment of intestinal GNs is by surgical resection since it responds poorly to medical therapy. GN are benign tumors that are cured after excision. Recurrence has not been reported. In very few cases, metastasis to surrounding lymph nodes was found. Intestinal GNs may be seen with diseases such as Cowden's syndrome, neurofibromatosis 1 and multiple endocrine neoplasia type $2 \mathrm{~B}$.

\section{Ethics}

Informed Consent: Obtained.

Peer-review: Internally peer reviewed.

\section{Authorship Contributions}

Surgical and Medical Practices: S.B., T.E., C.A., Concept: S.B., T.E., C.A., A.A.A., Design: S.B., T.E., C.A., Data Collection or Processing: S.B., T.E., C.A., A.A.A., Analysis or Interpretation: S.B., T.E., C.A., A.A.A., Literature Search: S.B., T.E., C.A., A.A.A., Writing: S.B., T.E., C.A., A.A.A.,

Conflict of Interest: No conflict of interest was declared by the authors.

Financial Disclosure: The authors declared that this study received no financial support.

\section{References}

1. Soccorso G, Puls F, Richards C, Pringle H, Nour S. A ganglioneuroma of the sigmoid colon presenting as leading point of intussusception in a child: a case report. J Pediatr Surg 2009;44:e17-e20.

2. Charagundla SR, Levine MS, Torigian DA, Campbell MS, Furth EE, Rombeau J. Diffuse intestinal ganglioneuromatosis mimicking Crohn's disease. AJR Am J Roentgenol 2004;182:1166-1168. 
3. Fenoglio-Preiser CM, Noffsinger AE, Stemmermann GN, Lantz PE, Peter GI. Gastrointestinal pathology: an atlas and text. 3rd ed. Philadelphia, PA: Lippincott Williams and Wilkins. 2008:555-559.

4. Chang CY, Hsieh YL, Hung GY, Pan CC, Hwang B. Ganglioneuroma presenting as an asymptomatic huge posterior mediastinal and retroperitoneal tumor. J Chin Med Assoc 2003;66:370-374.

5. Shimada H, Brodeur GM. Tumors of peripheral neuroblast and ganglion cells. In: Bigner DD, McLendon RE, Bruner JM, eds. Russel and Rubinstein's pathology of tumors of the nervous system. Vol. 2. 6th ed. London: Arnold. 1998: 493-533.

6. Geoerger B, Hero B, Harms D, Grebe J, Scheidhauer K, Berthold F. Metabolic activity and clinical features of primary ganglioneuromas. Cancer 2001;91:1905-1913.
7. Inci I, Turgut M. Neurogenic tumors of the mediastinum in children. Childs Nerv Syst 1999;15:372-376.

8. Shekitka KM, Sobin LH. Ganglioneuromas of the gastrointestinal tract: relation to Von Reckling-hausen disease and other multiple tumor syndromes. Am J Surg Pathol 1994;18:250-257.

9. Rubesin SE, Herlinger H. Small bowel: differential diagnosis. In: Gore RM, Levine MS, eds. Textbook of gastrointestinal radiology. 2nd ed. Philadelphia, PA: Saunders. 2000:884-890. 